\title{
THE LANGUAGE OF REAL LIFE: BATU PAHAT, 1900-1941
}

\begin{abstract}
by
Shaharil Talib

We Muslims do not chase money. That is the Chinese way.. we something we must make a profit in order to live: hut otherwise we make our living from the soil. We do not chase money for the sake of money. We want money to huy food and other things. The Chinese live to make money - that is their affair. We want money to live
\end{abstract}

The District of Batu Pahat, in the State of Johor, forms the subject of this enquiry. Johor is the third largest State in British Malaya. In the twentieth century it became the largest exporter of arecanuts, coconuts, rubber, pineapples and oil palm for the whole of Malaya. The commoditization of the economy structured the agrarian history of Johor in this century. The district of Batu Pahat emerged as the coconut district of Malaya; one of two arecanut centres of Johor and withnessed an unprecedented expansion of rubber in its inland areas. The emerging new material conditions carried with it the cultural birth-marks of an older social order built on production for use-value. The Malay proverb "Biar mati anak, jangan mati adat" (Let the child die but lest not the custom die out) re-entorces village solidarity). Malay peasant commodity producers in the market economy toiled the land to maintain their social life, while others more advantageouly placed profited from their labour. The new of intolerance, prejudice and racism have to be understood in the context of the expansion of twentieth century capitalism that preached the accumulation of wealth as its creed.

'Kenelm O.L. Burridge "Race Relations in Jehore". Australian Jeurnal of Poltucs and History, Vol. 2, No. 2, May 1957, 163-164. 
The District of Batu Pahat covered an area of 954 square miles or $610.0(0)$ acres of peaty and swampy lands. ${ }^{2}$ Early settlement was confined to a narrow belt of low lying land running for forty miles along the coast. At its heyday, during the 15 th century, the Sejarah Melayu (Malay Annals) mentioned that "...in the days of Sultan Mahmud a man might pass from Melaka to Batu Pahat without a torch, whereever he should stop, there would be houses and men"3. However, unstable economic and political conditions in the 19th century depopulated the district. At the turn of the century only 40,000 acres were cultivated by peasant small-holders hugging the length of the coast-line to a depth of a mile. and along the banks of both Simpang Kanan and Simpang Kiri for about 15 miles up-river. ${ }^{4}$ Coastal Malay peasants had built a fairly elaborate parit (drain) system which drained the water-logged area. About 128 parit were maintained in $1911^{5}$. Agricultural production was essentially for home consumption. However, copra and arecanuts were some of the main peasant produce that found its way into the market. Much of this trade was for the Singapore market. It was in the hands of small Chinese traders who collected the nut and exported them. There were indications in some areas these merchants had firmer control over production by renting coconut and arecanut kebun (holdings). Profits from commodity trade were substantial enough to support oa fairly large number of Chinese traders. ${ }^{6}$ The signs of economic raltions running along ethnic lines were already present at the level of limited market echange.

In the 19th century gambier and pepper planters moved into the District beyond the coastal belt. They pushed further inland and upstream in search of high and dry ground.' These two commodities were cultivated by Chinese immigrants backed by Singapore capital. The District never really einerged as a gambier and pepper producing country. However, these two commodities were the early agricultural produce that were sold on the market. Gambier and pepper were usually planted to-

2GAJ 434/1938: AR, LOBP, 1937.

'CLM 67/1912. AR, LOBP. 1911.

"Itud., 1 and 5.

CLR, BP $87 / 1911$.

'ARJ. 1910, 6.

'CLM. 67/1912: AR. LOBP, 1911, 1.2. 
gether. The former required little care but considerable labour force was needed for the harvesting of gambier leaves. Pepper on the other hand required continuous attention. The joint production ensured the maximum utilization of a labour force. ${ }^{x}$ Chinese labour was kept in near servile conditions. The kangchu usually held the five monopolies within his kangkar - sale of spirits, opium and pork and the operation of pawn shops and gambling houses. Economically the financier and his agent kept labour in perpetual dependency. ${ }^{9}$ The maximization of profits dominates social relations. Class domination is the underlying theme of material history.

The gambier and pepper industry, which was once an important source of revenue, began to decline towards the end of the 19th century. Prices were low making labour difficult to retain. The opening of the Johor offered cash wages to coolies and a backdoor exit. The archaic kangchu method of production broke down. In 1911 there were only 21 kangkar areas in cultivation and many were in state of decay. ${ }^{10}$ In that year it produced only 442 picul ( 1 picul $=133.3$ pounds) of pepper and 4,871 picul gambier. ${ }^{11}$ Batu Pahat District produced only a small fraction of the total exports of Johor for that year which amounted to 47.512 picul pepper and 212,386 picul gambier. ${ }^{12}$ At the 1913 prices of $\$ 19$ (black pepper) and $\$ 8$ (gambier) it was fairly profitable to grow the former and losses were made on gambier. ${ }^{13}$

At the dawn of the twentieth century, there were new signs on the commodity market horizon. Rubber was this century's phenomena. It locked the District into the world economy. Global processess were rooted into the countryside. World history began to shap the emerging social order. Peasants, labour and capital drawn from all quarters of the world arrived in Batu Pahat. Vast areas were cleared for rubber cultivation. The older gambier and pepper plantations were converted. Some of the released Chinese labour force placed themselves on smallholdings or openedup shops. New areas were opened between the established co-

\footnotetext{
"ARJ, 1910, 5.

'CLM 67/1912: AR, LOBP, 1911. 2-3.

${ }^{10}$ Ibid.

"GA] 172/1915: AR, AABP, 1914. 4.

${ }^{12}$ ARJ, $1911,3$.

13ARJ, $1913,4$.
} 
conut and arecanut helt along the coast and the inland $5.4 m$ tet and pepper strips. The rubher estates were initially wejged in

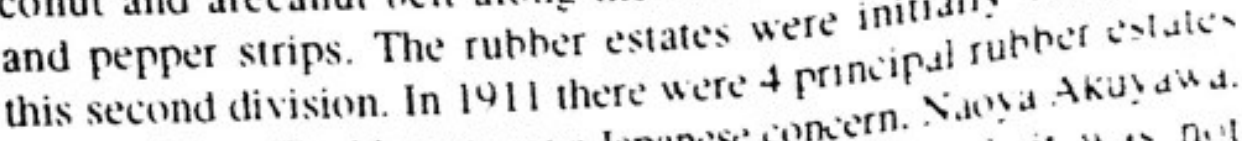
in Batu Pahat. The higgest was a Japanese concern. Tale thuy dis d. covering only 3.(1)() acres. ${ }^{14}$ In the decades ahead. it was 0.1 plantation rubber that made its mark in the District Batu Pahd emerged as essentially a District of peasant proprieters resporiving to market forces. ${ }^{15}$ New settlers poured intw the Drstrin in the early decades extending the areas of commercial cultiv ation Living oft the Malay peasantry in the making were merchant and usury capital offering their services - collectun. Iranyprertation, storage, treatment. sale, import. export. retall. whilesie and credit facilities.

The first forty years of the 2oth century in Batu Pahat District witnessed an accelerated economic expansion. unier. not by big mining concerns nor plantation houses. It was the industrious and indomitable small-holder. built around the tam. ily institution, that pioneered the countryside : The sucial order that was built in this District was on the toil of the small peasant producer. He was the owner of the means of production. forces of production and his labour. The fruits of his eftort uent for subsistence and the balance of the surpluses went in part 1 payment of dues to the Colonial State and in part as profits te a chain of middlemen. In essence an edifice of social classe: lived off him. The emerging social order at the local $u d s$ termined by market forces and the colonial State which nanimered its laws based on private property. capital accumulation and commodity production on the toiling masses.

The population data showed the District peopled hy imm:grants. In 1911 the total population was 27.612 of which $\$ .144$ lived in the town of Bandar Penggaram." Ten years later the population rose to 48.471 and in 1931 it registered 120.10 " The 1931 Census accounted for 75.722 Malays and 37.229 Chunes The Malay category covered a range of peoples from the Midis: world. About 39.(1)(x) were of Javanese stock and $12 .(x)$ Banjare

"CLR, BP 67/1912: AR, LOBP, 1911, 4

"CLR, BP 1490/1939: AR, LOBP. 1939,1.

"Ibud.

"GAJ 172/1915: AABP. 1914, 16.

19CLR. BP 2211934: AR, LOBP, 1933, 1. 
which made them the higgest communities of this kind in the Malay Peninsula. In 1933 the Superintendent of Census, C.A. Vlieland, commented that "Batu Pahat... has been the seene of immense agricultural development during the past decade and shows of percentage increase in population greater than any other district in Malaya."19

Only five other Districts in British Malaya had a higger population. ${ }^{20}$ In mid-1933 the population increased to $147,30(0) .{ }^{21}$ By this time, for the second year running Batu Pahat had the highest Land Office collection in Johor, overtaking Johor Bharu by $\$ 206,(0)(0)$ and Muar by $\$ 114,(0)(0)$. The land revenue for 19.33 was ten times the total revenue of the District from all the sources in 1910.22 Three years later the land revenue figures reached the qiddy heights of $\$ 1,751,312$ which made the District the largest collector of any single Land Office for all of British Malaya. ${ }^{23}$ It was the shoulders of the small-holder that carried the full weight of the colonial tax apparatus at the local level. The "civilizing role" of the colonial state had its in-built class prejudices, intolerance and racism.

In the 20th century, rubber rapidly outstripped the traditional exports of the district - arecanuts, copra, pepper and gambier. In 1911 only 165 piculs of rubber were exported. Three years later the export figures for rubber showed its potential. It increasd dramatically to 5,507 picul while arecanuts stood at 154,944 . copra at 64,332 , pepper at 7,887 and gambier at 14,539 picul respectively. In 1914 arecanuts, coppra and rubber made up more than $80 \%$ of the custom's revenue. ${ }^{24}$ Almost all of the export commodities were produced from small-holdings. ${ }^{25}$ By 1918 rubber clearly domminated the rest. Out of an export value of $\$ 187,933$ for the District, arecanuts formed $20 \%$ copra, coconuts and coconut-oil another $23 \%$ and rubber $48 \%$. Gambier and pepper had declined in importance. These two traditional produce had a market value of only $\$ 4,706$ and $\$ 3,373$ respec-

\footnotetext{
"9lbid

${ }^{20}$ Ibid., These were Kinta, Perak (250, 558), Kota Bharu, Kelantan (165, 412). Muar.

oliore $(150,452)$, Kota Setar, Kedalı $(138,805)$ and lowwer Perah (127. 125)

"Ibid.

"Ibicl., 2.

2'Ibicl.,p. 2.

${ }^{24 G A J ~ 202 / 1937: ~ A R, ~ L O B P . ~ 1936, ~ p .1 ~}$

${ }^{29} \mathrm{GAJ}$ 172/1915: AABP, 1914. p.4.
} 
tively. ${ }^{26}$ An ethnic interpretation of history will blur the class cleavages that has emerged.

Vast areas of the District's hostile and difficult terrain were tamed by the Malay peasantry. Armed with parang, hoes and muscle power they made the land productive. In 1933 a total of 346,000 acres were under cultivation. Rubber and coconuts were the dominant crops. The former covered 156,000 while the latter 150,000 acres. The other crops lagged far behind in acreage. Arecanuts were planted on 14,000 acres, padi 11,000 acres and oil-palm which was then a newly introduced crop 10,000 acres. Fruit trees, tobacco, gambier, pineapples and topioca covered the balance of 5,000 acres.

The opening up of Batu Pahat District was a peasant response to 20th century processes dominated by the global expansion of capital. From about 40,000 acres at the turn of the century, this frontier District grew in the decades ahead beyond recognition. The peasantry was the back-bone of the District. It was always in the making as immigrant groups peopled the District. The older core of the peasantry were the pre-1896 settlers who opened areas under the authority of the penghulu. This patriachal institution came to dominate the coastal belt of Batu Pahat District. Almost all Malay small-holders were united under the penghulu for the common upkeep of the surroudings - drains. structures and pathways. The penghulu's influences permeated within a well recognised kawasan. All newcomers would approach him to settle within the Kawasan Penghulu. The will and personality of the penghulu dominated his kawasan. It developed as an independent "imperium in imperio". ${ }^{27}$

The early settlers had little administrative contacts with the royal capital of Johor Bharu. The State imposed a 5\% export duty on what little produce that came out off the District. This duty was paid by Chinese traders who collected the produce at the source. Peasants did not pay any form of agricultural taxes. Occasionally the dominant ruling class centred outside the District would demand labour services known locally as upah seraya. ${ }^{29}$ This was for the maintenance of drains and paths, roads and

20Ibid., p.7.

${ }^{21} \mathrm{GAJ}$ 216/1919: AR, AABP, 1918, p.3.
${ }^{24} \mathrm{CLR}$, BP 86/1911.

"Ibid., 3 and 18. 
structures and for the attendance on the ruler. At the village level the peasants daily remake their life.

The making of the commodity producer of Batu Pahat was a continuos process. In 1910 to Colonial State at the District level set out to create the historically necessary conditions for the expansion of capital. A British Land Office was appointed and in the decades ahead the usual administrative apparatus at the local level was erected. It provided the services essential for export production by countless Malay small-holders. Railways, postal, telephone, roads, ports and other service infra-structures were built and maintained. The District Office was the nerve centre which regulated the relations of production and exchange. Hundreds were engaged by the Colonial State' for this purpose at the local level. Malay land Officials, parit inspectors, forest guards, municipal workers and a host of others were servants of the Colonial State. Their functions were reduced and simplified to simple operations such as registration, filing and checking for which they earned workingmen's wages. The Land Office in 1914 reported that correspondence increased considerably during the year. There were 1,932 minute papers registered in that year as compared to only 226 for the previous year. ${ }^{30}$ The intolerance and prejudices of the Malay producing classes in relationship to an equally demanding Colonial State was mellowed by an apparatus staffed by Malays.

The agricultural possibilities of the District were recognised by small-holder families with the expansion of the market aconomy. The District was continuously filled by waves of immigrant groups from the larger Malay world who swelled the numbers of the peasantry. Their arrival usually followed the ebb and flow of market prices. These groups came from neighbouring regions. In 1910 and 1911 there was a large scale immigration of Javanese and Banjarese into the District. The boundaries of the once narrow settled coastal belt began to expand. Villages multiplied in numbers. In the early phase, the Indonesian immigrants, were pioneers who came to raise enough cash to cover the cost of the pilgrimage to Mecca and to make enough to return home. The pilgrimage ships used to stop at Singapore from where they disembarked and found the way to Batu Pahat

${ }^{20}$ CLM 189/1915: AR, LOBP, 1914, 8-9. 
and elsewhere. They came to earn enough to cover at least the basis $\$ 3(0)$ cost of the pilgrimage and with the balance they hoped to purchase a piece of land in their native $k$ person soon as they arrived in the District they found a person with a little capital and opened 8 acres or so on land. Thei tion being their food and half share on the land when they had planted it. Many did not return home after establishing their homesteads in the District. ${ }^{31}$ The cash economy served only for their continued production and reproduction.

The attractive market prices for arecanuts. copra and rubber and the abundance of land precipitated a land rush in the first two decades of the 20th century. New areas were continuously brought under cultivation. The peasant houschold was the basic social unit which pioneered the countryside. Production capital which operated in the estates was unable to recruit and retain a stable labour force because of the high rubber prices. Everyone wanted to occupy land for himself. ${ }^{32}$ The price of cultivated small-holdings too increased in value. In 1914 the value of a coconut small-holding in bearing or a rubber plot in tapping was $\$ 300$ an acre. ${ }^{33}$ Two years later the asking price was $\$ 1,000$ per acre. ${ }^{34}$ In that year about 2,334 new Malay immigrants arrived via Singapore. ${ }^{35}$ In jungle areas, the Land (Office allowed these applicants to go straight into occupation upon payment of the necessary fees. The majority of these newcomers in 1916 arrived in the first 5 months of that year. They continued to fill up the mukim of Sri Gading. The price of rubber remained high. About $50 \%$ of the land applications were made in the first ? months of that year. ${ }^{36}$ These Malay immigrants "... moved into small-holdings of rubber, betel, and coconuts - felling and clearing the jungle, straightening out the tributary streams and, where these were lacking, built their own canals, or parits, to connect them with the rivers, and placing their homesteads with plenty of room between them along either bank - the Chinese moved into the towns and villages, and higher land. ${ }^{37}$ Malays toiled the

"GAJ 135/1916: AR, AABP, 1914, 2 and 13.

"GAJ 135/1916: AR, AABP, 1915, 3.

"GAJ 172/1915: AR, AABP, 1914, 13

MGAJ 166/1917: AR, LOBP. 1916, 5.

"GAJ 166/1917: AR, AABP. 1916, 3.

"GAJ 166/1917: AR, LOBP. 4.5.

"K.O.L. Burridye, "Race Relations in Johure".154 
land daily and hourly to satify the needs of their material life. Other social classes profitted from their labour.

There were other more specific reasons that made the District attractive to settlers. The Colonial State in 1914 introduced a new enactment that allowed for a $2.5 \%$ duty on exports of agricuitural commodities for land registered under the Land Enactment. Those areas that were not registered continued to pay the previous rate of $5 \%$ ad valorum for exports. This new incentive led to rush for conversion of land titles and an increase in registration. In 1915 the land records showed an increase for land grants. There were 249 applications in that year as compared to 173 in $1914{ }^{3 *}$ Entry Mukim Register titles too increased in demand. There were 2.351 applications as compared to 1,097 in 1914. Private property became the basis of commodity production. The market prices determined the crop the peasant produced. The expansion of global capitalism witnessed a rapid reproduction of peasant villages. Visually a typical contry scene was:

Hard by the main river a parit a few shops occupied by Indian or Chinese are to be found. Further-up, the houses are large. built on stilts, well-spaced and sited in the shade of fruit trees. betel, coconuts, or rubber trees. The immediate environs of the homesteads are kept clean and neat; a bordered path ledds to the high porch; stepping stones show the way to the wellkept shrubs and flowers make a pleasant garden. Inside the house the rooms ar large, cool and clean. The atmosphere is one of calm and patient content. Overall lies the stillness of sleep. ${ }^{39}$

Standing back from the details of the peasantry in the making. it is essential to bear in mind that there were other classes emerging in the social order. The Malay wage-earning officialdom had been alluded to earlier. Their influence was much out of proportion to their numbers. The coolies who worked the gambier and pepper gardens dissolved with the advent of wage-labour and rubber. They moved into the peasantry. There was a small group of wage-labourers that worked in the rubber estates but their permanency was never assured. They applied for their own rubber plots. The Malay peasant small-holder formed the producing class in the District. The fruits of his labour were brought

"K.O.L. Burridge, "Race Relations in Johore"., 155. 
into the market through an elaborate network of exchange re. lations dominated by ethnic Chinese. In every instance where the jungle was tamed by cultivators, merchants and usury capitalis arrived shortly. This social class lived in the pores of the ag. ricultural society. The trader collected the produce from the peasants for a small sum and sold it on the market. The trader even went further. He secured from the cultivator the right to the produce of the land in advance..$^{40}$ At the ground level these Chinese traders were creditors, advancers of food supplies, purchasers of produce, retailers and performed a multiplicity of other serv. ice functions. They exacted their profits in each transaction.

The commercial centers were in towns and large villages. The contrast with rural producers was most stark.

"Towns and villages present a sight of closely-packed shophouses on either side of the main and subsidiary streets, together with huddles of dwellings, store-houses and miscellaneous structures. Chinese predominate and create the basic social environment.... The whole village-dwellings. temples, workshops, coffee-shops, eating houses, trading agencies, schools and play spaces - is built on piles in an intricate maze of platform and catwalks. The cottates of Chinese farmers, built on hardened earth cheek by jowl with their populous pigsties, are scattered on the lower slopes of hills, tracing the contours". 4

At a higher level the entrepreneur was quick to seize the opportunities of an expanding economy. In 1914 the local Chinise towkay of Bandar Penggaram spoke of establishing factories for the processing of rubber. Others ventured out to purchase rubber. In that year there were 14 shop-keepers who held licences to purchase rubber and 1,172 persons obtained licences to store rubber. The figure almost doubled that of the previous year." In 1915 the first rubber factory was opened. That year also saw the setting-up of a machine scrap factory and an ice factory." There was talk of even setting-up a proper coconut-oil factory." The District had all the elements of a pioneering society experiencing a boom until the downturn of commodity prices.

"GAJ 172/1915: AR, AABP, 1914, 3.

"GAJ 172/1915: "Race Relations in Johure., I55

"GAJ 135/1916: AR, AABP, 1914, 7.8.

"GAJ 1721915: AR, AABP, 1915, 6. 
The feverish spirit of an expanding economy did not last very long. Towards the end of 1917 the rubber prices began dipping and the small-holders immediately felt it. They sold their uncleaned rubber sheets (poor quality rubber) for half the price of clean rubber. The price of copra too took a beating in that year. It was so low that cultivators did not find it worth the while plucking the nuts. ${ }^{45}$ The following year was also a lean one. The market prices of primary commodities remained depressed. The small-holder found it difficult keeping body and soil together. The world capitalists crisis scarred the Malay countryside. There was a singnificant drop in land applications. The colonial revenue base suffered. Many could not pay the annual State land dues and this was reflected in the increase in arrears. The number of licensed rubber dealers too declined. Many Banjarese Malays in that year simply abondoned their lands and returned to their native country. ${ }^{46}$ The harsh realities of capitalism closed a chapter in the experience of peasantry. The Chinese trading class dug deep into their monetary reserves.

With the exception of the years 1918 and 1921-22, the period 1918-27 was characterized by high rubber prices. The price of copra too maintained well above the 1917 low of $\$ 7$ per picul. The peasants produced to sell and with the money gained, they purchased their life supporting material necessities. Thousands sold the fruits of their labour through an elaborate network dominated by Chinese traders leading to international markets. In a buoyant market, the Malay peasants sold their produce, as before to buy commodities for home consumption. Commoditity fetishism dominated the market structures. The traders rapidly recovered their privious losses and continued to appropriate peasant labour.

The specificity of market conditions shaped rural history. The intolerant Colonial State discouraged rubber cultivation by Malay small-holders. However, the anti-rubber small-holding efforts failed. Like King Canute, colonial officials did not succeed in turning back the tide of commodity fetishism. They had their hands full implementing the rubber Restriction Scheme. up-dating the existing land records, collecting revenus and executing

"GAJ 143/1918: AR, LOBP, 1917, 5.

"GAJ 100/1919: AR, LOBP, 2-3. 
The feverish spirit of an expanding economy did not last very long. Towards the end of 1917 the rubber prices began dipping and the small-holders immediately felt it. They sold their uncleaned rubber sheets (poor quality rubber) for half the price of clean rubber. The price of copra too took a beating in that year. It was so low that cultivators did not find it worth the while plucking the nuts. ${ }^{45}$ The following year was also a lean one. The market prices of primary commodities remained depressed. The small-holder found it difficult keeping body and soil together. The world capitalists crisis scarred the Malay countryside. There was a singnificant drop in land applications. The colonial revenue base suffered. Many could not pay the annual State land dues and this was reflected in the increase in arrears. The number of licensed rubber dealers too declined. Many Banjarese Malays in that year simply abondoned their lands and returned to their native country. ${ }^{46}$ The harsh realities of capitalism closed a chapter in the experience of peasantry. The Chinese trading class dug deep into their monetary reserves.

With the exception of the years 1918 and 1921-22. the period 1918-27 was characterized by high rubber prices. The price of copra too maintained well above the 1917 low of $\$ 7$ per picul. The peasants produced to sell and with the money gained, they purchased their life supporting material necessities. Thousands sold the fruits of their labour through an elaborate network dominated by Chinese traders leading to international markets. In a buoyant market, the Malay peasants sold their produce, as before to buy commodities for home consumption. Commoditity fetishism dominated the market structures. The traders rapidly recovered their privious losses and continued to appropriate peasant labour.

The specificity of market conditions shaped rural history. The intolerant Colonial State discouraged rubber cultivation by Malay small-holders. However, the anti-rubber small-holding efforts failed. Like King Canute, colonial officials did not succeed in turning back the tide of commodity fetishism. They had their hands full implementing the rubber Restriction Scheme, up-dating the existing land records, collecting revenus and executing

"GAJ 143/1918: AR, LOBP, 1917, 5.

"GAJ 100/1919: AR, LOBP, 2-3. 
other land matters. In the meantime, on the blind side, rubber cultivation expanded unnoticed. A testimony of this thrust was the undetected opening of Yong Peng by Chinese small-holders at an astonishing rate in the interior mukim of Tanjong Sembrong. Stunned officials estimated in 1932 that in the period between $1926-32$ about $36,(0)\left(0\right.$ acres were opened. ${ }^{47}$ Elsewhere in the District another $22,8(0)$ acres under rubber cultivation were unrecorded by the Land Office:48 $10,(0)(0)$ acres of which were on the Johore Bharu road. ${ }^{4}$ The rubber expansion at Yong Pang. often backed by Chinese capital, consisted of well planted rubber on undulating land within easy reach of road, rail and river. The planting hegan at the end of 1926 and reached its height in 1929; died down towards the end of 1930 and stopped completely by the end of 1931. Choice land was selected within a 45 mile circumference. Over 20 miles of road frontage was taken up along the Yong Peng road. In other places, the unauthorized rubber blockes were 5 miles south of Yong Peng; 10 miles north on the Labis road and 10 miles east on the Paloh road. H.W. Hamilton, the Acting Chief Settlement Officer. Batu Pahat wrote in amazement "Many acres of jungle trees were brought to earth to reveal mathematical rows of Hevea Brasiliensis"."

A decade of accelerated agricultural expansion between 1918 and 1927 subjugated about half the difficult coastal peat lands for cultivation and pushed back one-third of the tropical jungles on the inland hill slopes..$^{52}$ The peasant laboured for the one great market provided by industrial capital. In the world of commodities the market was where the products of individual small-holders were exchanged as commodities. The historical epoch of producer-consumer within localized communities of villages had withered away. Commodity fetishism was the expression of the changing material conditions of history. The industrial market increasingly made local, national, regional and international communities depend on each other for the supply of raw materials, instruments of labour, finished products and

\footnotetext{
'Draft Memorandium, unsigned, undated, in CLR, BP. 617/1932.

"Enil. S. Land Dues (Outstanding. Batu Pahat, in CLR, BP 802/1932.

49nd. 2. Menoranilum by CLM. Johore, undated, in CLR, BP 802/1932.

wDraft Memorandum unsigned. unilated, in CLR, BP 617/1932.

"Memerandum on the operations of the "Settlement Arrears Scheme" at Batu Pahat. Johore. 193.19-198. (Henceforth, Settement Arears Scheme). H.W. Hamilton. Actink Chtef Settlement Officer, Batu Pahat, 9.

'Ibit., 1.
} 
even human producers themsmelves. The contradictions of the global production and expanded reproduction of capital unfolded itself with the disintegration of the market economy. In this context "The Malay... small holder is almost entirely at the mercy of events and motives which lie not only outside his control but often outside his comprehension. Chinese primary producers are much more securely placed: being mixed farmers, what they lose on bananas they make up in pork or in vegetables. Annual floods are no menace. And the Chinese who very commonly form limited companies (kongsi) usually have sufficient capital behind them to ride out vegaries on the market. Even more resilient are the legions of Chinese middlement who stand between production and eventual consumption" ${ }^{23}$. Class expressions in the social order remained rooted along ethnic lines.

The catastrophic slump of 1928-33 stands out in bold relief as a period by itself. The prolonged historical experience of those lean years set it apart from the previous short-lived downward commodity price trends of 1918 and 1922. On 31 October 1928 the Colonial State lifted the Rubber Restriction Scheme which had reined in and regulated the expansionary strides of rubber small-holders. ${ }^{54}$ The open market economy in that year took a beating. Wholesale rubber prices plummated from a monthly average per picul of $\$ 85.73$ in 1927 to $\$ 49 .() 0$ in 1928 and maintained a downward trend until it reached rock-bottom at $\$ 9.29$ per picul in $1932 . .^{55}$ In the Singapore market there were sufficient monthly fluctuations which affected violently the price mechanisms at the local District level. At the production level the Malay Small-holder sold his rubber in katies $(1 \mathrm{kati}=$ One and one-third pound) daily often to bicyle-riding Chinese middlemen for his daily needs. During the bleak months of 1932 until the middle of 1933 the monthly wholesale price at Singapore stagnated between six and fourteen cents per kati. In 1934 a new scheme of Rubber Regulations was introduced. The monthly average wholesale price inched up to $\$ 27 .(0)$ per picul. Until World War II, rubber prices never again reached the heights of pre-Depressions years. The rubber index was the life sustenance

"K.O.L. Burridge, "Race Relations in Johore", 158

"GAJ 90/1929: AR, LOBP, 1928, 12.

"Malaya: (Avarage Prices Declared Trade Values. Exhange, Currency. and Cast of Living for the year 1932.) Department of Statistics, S.S. and F.M.S., Government Printing Office, Singapore, 1933, 6. 
pulse of the countryside. Thousands of Malay peasants depended on rubber tor a livelihood. The other commodity exports on the district, many coconuts and to a lesser extent arecanuts, followed similar downward price trends. The falling tendency was distinct. However, the monthly average price of copra reached its lowest at $\$ 2.93$ per picul in 1934 when rubber was on the up-swing. The immiserizational of the peasantry at the local level during these years was determined by the world capitalist crisis. The exploitative characteristics of capitalism was personified in the Chinese trader.

The over-demanding colonial state more than in any other earlier period intruded far into the peasant commmodity production base ensuring payments, cultivation and maintenance. The office of the Collector of Land Revenue, Batu Pahat was re-organized and each senior officer and his clerical staff were assigned specific functions. ${ }^{56}$ The office work-load was bogged by bureaucratic entries, receipts, registrations, minutes, memorandums, procedures and other paper work. A more systematic flow of work increased revenue collection. ${ }^{57}$

The burden on the small-holder to settle his account with the Land Office ws heavy under poor market conditions. Innumerable of small-holders were hard hit by the slump. They raised the money to make the necessary land payments and feed themselves. Large land owners on the other hand were given favourable treatment. Prejudice and intolerance coloured colonial policies. Those whose annual rents exceeded $\$ 100$ were permitted to pay fine instalments spread over the year. It was only after 1933 that similar considerations towards the peasantry were made. Peasants trudged to the rent collecting windows of the Land Office and paid their dues. Others settled their accounts through the local headmen who were entrusted to forward the payment. They also contributed usually 50 cents each for transport expenses which saved themselves time and trouble. The rest paid their dues at the well publicized field trip collections organized by the Land (Office..$^{5 x}$ In 1932 the sum of $\$ 88,00($ ) from a total of $\$ 410,377$ was collected through 68 field collections. ${ }^{59}$

\footnotetext{
"Encl.. Collecting Revenue by Stamps, C.R, BP, 22 June 1933, ia CL.R, BP $510 / 1933$

sesee Minute. C1.R, BP, I August 1933 and Encl., 4, CLM, Johore to The State Sectetary.
Jiniore. I July 1933, is CI.R, BP 1353/4933.

"AA, BP 109/1933: AR, LOBP, 1932
} 
The life of the Malay peasant family was desperate. They were financially pressured by the State against the backdrop of poor commodity prices. Everywhere the peasants went into debts. In 1932 Mukim VII, Tanjong Sembrong, owed $\$ 28,()(k)$ for arrears and $\$ 37,000$ for current rent. The total of $\$ 65,(0)(0)$ made it the highest mukim in debt to the Colonial State in District. The peasants sold jewellery and paid land rent and pruchased food. Two field trips in that year could only take in $\$ 2(0)$. The penghulu Haji Ali bin Haji Abbas was reprimanded for inefficiency. ${ }^{61}$ The accounts of the peasant small-holder's earning capacity was revealing. A five acre lot of rubber produced an estimated six katies daily. From a monthly output of 1 picul and 80 katies at ten cents a $k a t i$ he ususally paid half to the absentee landlord on the usual pajak or bahagi dua system which left him about $\$ 9$ per month or 30 cents a day. ${ }^{61}$ The Commissioner of Lands and Mines, Johor in another estimate spoke of a six acre lot producing six katies daily at 15 cents a kati. The daily income of the peasant was placed at 75 cents from which he had meet expenses. The five acre coconut small-holder, on the other hand, harvested 12 picul annually and marketed the crop at $\$ 4$ per picul. His annual income was $\$ 48$ or $131 / 2$ cents daily. ${ }^{62}$

Poor commodity prices, State financial demands and the cost maintaining the family's basic necessities, left the peasant little hope for survival. The historical conditions of the capitalist crisis restructured the social relations of production of the immediate producer. The small-holder mortgaged and even sold their holdings. Socia! differentiation occurred at an unprecedented scale. The notorious pajak or bahagi dua system was rampant in the countryside. The basic means of production was wrested from peasant hands. The non-cultivating class of Chinese merchants and mostly indian usury capitalists dominated. Land officials were struck by the "... immense amount of absence ownership" usually found in the areas held by Surat Sementara and Daftar Permohonan (Approved Application). Two fairly extensive areas were examined to evaluate the bona fide-occupation of the lands. "One area selected as typical of the sparsely populated area gave the result that one holding in twelve supported a house

${ }^{\infty}$ Minute, CLR, BP, Undated on CLR, BP 250/1932.

"Minute E.A.P. Helps, CLM, Johore, 30 May 1933, on CLR, BP $510 / 1933$.

"End 7, CLM, Johore to the State Secretary, Johore, 15 August 1933. 
with resident occupation, and another count in a nearer and relatively populous area disclosed one in five." ${ }^{\circ 3}$ This was a high proportion hearing in mind that in 1932 there were $30,(0)(0)$ holdings on the Rent Rolls and another estimated $30,(0)$ holdings still registered ${ }^{64}$ The real owners of the lands lived in the towns and large villages; more often peasants "Under depresed their documents to the care of the chettiar." 65 Und market conditions, those with financial reserves moved in to seize control of the peasant's means of production. Capitalism unleashed its intolerances and prejudices. The colonial machine did little to defend the survival of the peasantry. They were literally "basket-cases".

The office waste-paper baskets daily bore off to the incinerators many touchingly worded requests to measure my lands which I have planted with rubber in order that I may get coupons to provide my daily needs for myself and my numerous family. ${ }^{66}$

Absentee land ownership prevailed in the countryside, especially in the coastal areas. "Of the many thousands of Surat Sementura that have been issued it is an indisputable fact that a very large proportion have fallen into the hands of money lenders, the original holders having partly or entirely abandoned their claims". the usury and merchant capitalists advanced their interests on the misery of the peasantry and the extravagance of the landed magnates. Once the clutches of money lenders gripped it resulted in the ruination of rich landed proprietors and impoverishment of the small producers. At a higher leverl there was a build-up of concentration of large money capital. Usury capital eventually expropriated the means of production from the peasant. The peasant borrowed out of necessity and repaid high interests and the principal. He was forced to reproduce his basic sustenance at even more pitiable conditions.

The full extent of chettiar ownership and mortgage might never be possibly known. However, in 1932 the Land Office made it possible for large landlords to pay their land rent in

"Settlement Arrears Srheme, 19.

"AA. 109/1933: AR. LOBP, 1932, 1

"Settlement Arrears Siheme, 19

"Ibid., 8-9.

"CL.R. BP 2156/1933: Chief Seuleunent Officer, BP to AA, AP, 20 October 1933. 


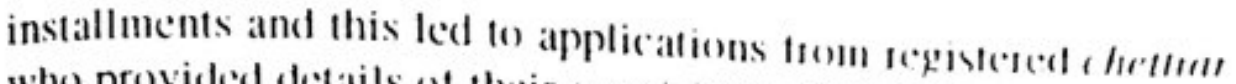

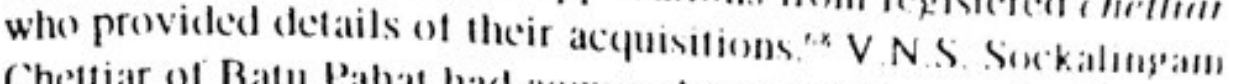
Chettiar of Batu Pahat had acqured over o(t) actes of culavithed land under different tilles from Surat Sementara lo grants." another chettiar with an unusually lengthy initials, S.K K K A K K Adappa Chettiar of No. 43, Jalan Penggaram, Balu l'ahal as quired 15 lots, most of them in Mukimn VII. Tanjong Sombrong it

Narayanam Chettiar on the other hand had his 45 holdings scattered throughout the District." In some casces cheltorr went about systematically picking up adjoining lots which ('ventually were amalgamated to form one single grant. The Al. P' Al.. MV Estate, covering. 310 acres, situated at the fith millestone l'aloh Road in the mukim of Tanjong Sembrong was formed in thes manner. This land was formerly held hy a number of chinese small-holders under Approced Application and Surot Sementara. About 116 lots ranging in size from one to ten acres were sold to A.L.P. Palaniappa Chettiar and A.I.M. Muthuverappa (hettiar. son of Alagappa Chettiar. ${ }^{72}$ All of the above chettiar and registered addresses were at Jalan Penggaram. Batu Pahal and they formed an association known as Natukkotai Chettiar's Association. ${ }^{73}$

There was little that could be done to release the vice-like grip of the chettiar of the land-holding. ()nce in their hands. the land-owners were on the path of ruination. When considered in detail each case had a "hard luck" story. Haji Kiok bin Kahmat who settied in the mukim of Sungai Pinggan at the turn of the century and cultivated 117 acres of coconut land owned hy the early 1930's $\$ 8,(0)($ Sinniah Pillai Chettiar. He claimed himself a chief and the eldest of the Bugis settlers in the mukim. He once wielded considerable influence and authority. His anak buah (followers) were mobilised to build an extensive drainage system for successful cultivation on mangrove swamp lands. They worked for him on the pajak system but it was reporied

"CLR, BP 6/1933 CLR, BP to CLM. Johoce, 8 January 1933

"Encl, 1, S.K.R.K.A.R.K. Adappa Chettyar, 17 March 1984. in ('I.K. BP 233/1'184

Chettyar. 17 Mach 1934, in ('I.R. Bl' 231/1034

${ }^{2}$ Encl. 1, S.K.R.K.A.R.K. Adappa Chelly (helliar to (Y.R. BP. 7 Match 19 is

"CLR, BP 234/1934: A.L.N. Narayanam (hellar fo (1.R. BP. Barch 1935, in CL.R. BP $526 / 1435$

${ }^{n}$ End. 1., CLR, BP to CI.M. Jolwre, 3

${ }^{3}$ CLR, BP 2800/1933.1934. 
that he left them in the lurch when the land came into bearing. The fall in prices affected him adversely. His compulsive spending habits did not help him either. He borrowed even be $\$ 125$ once Depression period. At 1934 prices he hoped to obtain $\$ 125$ at $\$ 5$ per every two months from $25 .(0)(0)$ coconuts coly will take possession of [his] only and entire property and thus [his] earnest and hard labour would result in
earth and disaster. $" 74$

The price of standard ribbed smoked rubber showed signs of improving in May 1933. It rose to 12 cents a kati as compared to 8 cents two months earlier. ${ }^{75}$ The average wholesale price in that year reached $\$ 27.50$ per picul maintained its improved position for the rest of the decade. However' rubber never reached the lucrative prices of the pre-Depression years. The spectre of starvation was removed from the rubber smallholder. The coconut cultivator, on the other hand, suffered reversals. The price of sun-dried copra reached the very dregs at the Singapore wholesale market in 1934. It was sold at a paltry $\$ 2.93$ per picul. For the remainder of the decade, coconut prices remained low.

The differences in commodity prices widened the gulf amongst the producing classes. The Malay coastal growers staggered behind the pace set by the flurry of activities of the inland Chinese rubber cultivators. In the post-Depression years the shift back into the market economy was distinct. The extensive acreage under the cultivation during the bleak years shrunk to only 65 acres in the 1937-38 season. It was only the distant drums of war that increased food cultivation activities again. Production for exchange value dominated the country-side. The historical conditions distinguished these years from the previous period. In its speciticity the role of the Colonial State was critical in accelerating this maturization. The Rubber Regulation Scheme and the intensification of land rent collections structured the producing classes in its social relations of production and exchange.

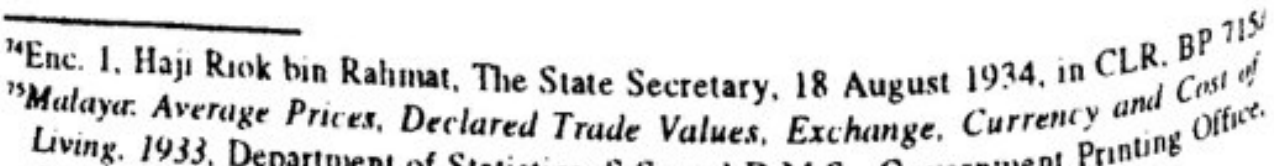
Living. 1933, Department of Statistics, S.S. and D.M.S., Government Printing Offit-
Singapore, 6 .
} 
(In 31st I)ecember 1941) the land records showed that 288.211 acres in the District were cultivated for the market aconomy. ${ }^{\text {?o }}$ Rubber, coconuts, arecanuts and more recently oil palm were the main export crops. The cultivation of coconuts, often mixed with arecanuts, covered extensive areas along the coastal belt. In 1433 about $150,(0)(0)$ acres were planted with coconuts. ${ }^{17}$ The District of Batu P'ahat was the largest coconut growing District for the whole of Malaya. Peasant small-holdings under ten acres was the dominant production unit. ${ }^{7 x}$ Coconut cultivation in Batu Pahat never really reached plantation proportions. ${ }^{79}$

The rubber industry was also characterised by peasant smallholders. In 1938 it was recorded that 74,859 acres were registered under 20,818 rubber holdings of less than 25 acres. A further 17.075 acres were planted in holdings of between 25$1(k)$ acres. The total area of rubber in 1938 below plantation since size covered 91,941 acres. Malay ownership dominated the small-holding sector. They occupied, 47,424 acres as compared to Chinese small-holders under 25 acres category who cultivated 25.281 acres. However, on the average the Malay small-holding lots were much smaller at 3 acres compared to Chinese-onwed lots at 5.1 acres. In the category of holdings between 25-100 acres Chinese onwers outnumbered the others. ${ }^{30}$ There were 300 such lots that covered 12.354 acres as compared to 43 Malay-owned holdings under 1,865 acres. Indian ownership on the other hand was negligible. The only significant feature was that they owned 45 lots covering 2,318 acres in the category of holdings between $25-1(0)$ acres. The concentration of lands in Indian hands were the results of money lending schemes. The District was essentially worked by peasant proprietors and proprietory planters.

Among the latter category Chinese and chettiars predominated. Plantation interests covered only an estimated $50,()()$ acres. Japanese-owned campanies held interests over 25,()() () acres of rubber plantations. In 1937 there were 5 Japanese plantations in the District and 9 others onwed medium-sized estates. They

\footnotetext{
"GAJ 69/1941: AR, L.OBP, 1940, I

"Enil. 3, CLR. BP to CLM, Jhore, 11 August 1934, in CLR, BP 74.5/1934

"End 2. Assistant CL.R. BP w CLM, BP. 3 April 1934. in (2LR, BP 745/1034

'End. 3, CL.R. BP to CL.R. lohere. August 1934, in CLR, BP 745/1934.

CLR, BP 46/I939: Nationality of (Ownership. Small Holalugs 1938.
} 
also owned the large iron and bauxite mines at Sri Medan and the bauxite mine at Bukit Pasir. European-owned plantations comprised the 25,0()() acre Johore-Labis oil palm and rubber estate. Yong Peng estate and two small estates near Batu Pahat. ${ }^{\mathrm{xi}}$ It was the non-Malay monied-landed proprietor who took advantage of the replanting scheme. The average Malay smallholder did not have the necessary cash outlay. He could not afford the risk of violating the law. In 1938 when rubber prices dipped again many Malay small-holders who possessed share certificates to replant disposed them to dealers, and owners of larger Asiatic holdings. These share certificates in the District fetcherd $\$ 1.0()$ and $\$ 1.20$ per one-twentieth share. ${ }^{\times 2}$

Profits from the rubber industry was made by the rubber dealers, owners of large holdings and plantations. In 19.34 there were 82 dealers registered in Batu Pahat District. Twenty of them were located at Batu Pahat town and another 21 at Simpang Kanan. The rest were scattered in the larger villages throughout the District. All the rubber dealers were Chinese except for 2 Malay operators. ${ }^{83}$ These Chinese merchants purchased at lower market prices from coupon holders and sold at a profit. Illegal tappers whose lots were unregistered and did not have coupons sold their rubber to these dealers who had in addition held licences for treating and smoking rubber. These merchants purchased from squatters and in 1934 took a commission of $\$ 1.50$ per picul and charged them also the cost of treating and smoking. ${ }^{* 4}$ Peasants with coupons but had no rubber found a ready market for their coupons. However, such dealings depended on market factors and State policies. A fall in price and cuts in coupon issued at any one point in time would lead to stoppages in peasant production. They would sell their coupons and seek alternative employment. Peasants moved in and out of the labour market. When rubber prices improved they would tap their own trees. ${ }^{\mathrm{xs}}$

The rubber dealers jealously quarded profits. They were quick to protest if others had an unfair advantage over them

"GAJ 59/1941: AR, LOBP, 1940.

"CLR, BP 267/1939: AR. Agricultural Officer, Johore Central. 1938. 4.

"Encl. 1, in CLR, BP 721/1934

"Encl. 3, in CLR, BP 721/1934.

"ARJ, 1936, P 16 and AR.J. 1937, 14. 
such as close proximity to Custom Stations. ${ }^{86}$ The profits they accumulated were loaned to small-holders and reinvested in the purchase of rubber lands, often small-holdings. Plantations too acquired part of their properties from small-holders. ${ }^{87}$ In 1937 it was noted that most of the Japanese rubber companies were purchasing large number of small-holdings. There were also cases of whole estates being formed entirely by the purchase of smallholdings. During the Depression years the formation of AL.P. AL. MV Estate was the most notable. In 1934 Yong Peng Estate bought out an extensive area of small-holdings in the mukim of Cheah and Tanjong Sembrong. ${ }^{88}$ In 1936-37 Low Lin Seng picked up 46 small-holdings which were in poor condition covering an area of about 227 acres. The area was located on the 4 th mile Yong Peng-Labis road. ${ }^{x y}$ The 32 plantations that existed in 1934 grew in numbers. ${ }^{90}$

The 1934 slump in copra prices was described as bad if not worse than the rubber crisis in 1931-32. Countless smallholders were seriously affected. Immediate measures were implemented to bring relief to the coconut industry. Those holdings that depended entirely on coconut cultivation were given a waiver on their holdings. Nine mukim were singled out for the rebate on land rent. In the following year the waiver was extended throughout the District. ${ }^{91}$ The slight improvement in prices in 1936 set the tax-collectors back in motion. The peasantry had hardly enough time to recover from their debts. The majority of the small-holders who were served summons and notices paid their dues but the remainder had to be dragged into the Courts. A large number of minute papers were opened, land registers were cross-checked, summons re-served and the parties affected re-notified on dates of postponement. The coconut small-holder was unable to pay land dues. Some areas were badly affected by floods.In 1934 over $8,(0)()$ acres in Mukim VIII, Batu Pahat were damaged by floods. ${ }^{y 2}$ For three and a half months the

\footnotetext{
"End. 4, in CLR, BP $573 / 1934$.

"CLR, BP 1005/1937.

"CLR,BP 1005/1937.

${ }^{\circ C}$ CLR, BP 34/1938: Report on Low Lin Seng Estate. Senior Rubber Inspection. BP. Undated.

"See List of Eastates in CLR, BP 438/1934.

"See Enclosures in CLR, BP 745/1934.

"Enc. 1, on CLR, BP 246/1934.
} 
flood waters refused to recede. Waited and fallen trees painted a gloomy picture in the countryside. The peasants could not pay the land dues and had hardly enough to feed themselves. ${ }^{93}$ The Courts were glutted with work and the unable to keep track of its own footprints. areas under coconut cultivation which had paid nominal depos. its for Daftar Permohonan titles. These documents were ready for conversation to the Entry Mukim Register titles upon full payment of back rent, premium and other fees. The chief Settlemet Officer feared that "... until the people are summoned they will neever pay this office so much a courtesy visit." ${ }^{\text {"9 }}$ Impersonal market forces nationalized the actions of the colonial state.

The plight of the coconut small-holder was in desperate straits. In 1933 when the price of copra was at $\$ 3.90$ per picul, he earned $\$ 13.90$ from an acre annually. He usually owned a five acre lot. The average cost per acre of coconut land was $\$ 2.0()$ rent and $\$ 7.50$ for the harvest and other work on the land. The usual harvest for an acre was 6 picul. In 1934 when the price dropped, peasants whose lands produced 4 picul per acre made only accounts an acre. The coconut groves were littered with ripened coconuts as it was not worth collection them. Itinerant buyers picked them at $\$ 3.25$ per thousannd nuts. Even an owner of a 6 to 7 acre lot was unable to make ends meet. The coastal grower could not fish during the South-West monsoon and could not cultivated padi on peaty soil. ${ }^{95}$ they leaseed their properties to Chinese money-lenders at very low rates. ${ }^{96}$ Human decencies were never counted.

Arecanuts were usually associated with coconut strands. Batu Pahat was one of two major centres in Johor where the palm was planted extensively. ${ }^{47}$ The arecanuts worn usually manufactured and sold as splits, whole. sliced and salted. There was a sepecialized China market for boiled immature arecanuts." However, in 1936 the trade in boiled arecanuts stopped as it had become unprofitable. The Mukim of Benut was the local manufacturing centre in the District. Malay peasants were the owner

"TLR. BP 207/1937: Chief Settlement Officer, BP to Aa, 12 January 1937. "CLR. BP 264/1934: CLR. BP to Tree, 4 April 1934.

"Encl. I, in CLR, BP 264/1934.

*ARJ. 1936, p. 20.

"ARJ. 1934, P. 17.

"CLR. BP 267/1939: The Ayriculture Officer. Johore Central, 1938. 11. 
of the holdings but the production and export of the various types of produce were in the hands of the Chinese. The owners sold the arecanuts or leased their holdings to ('hinese producers. The former found employment in splitting the nuts for the dealers. ${ }^{4 y}$ The prices of the commodity varied periodically and regionally. In 1938 the prices for split nuts fluctuated hetween $\$ 3.50$ to $\$ 7 .(0)$ per picul within the surroundings of Batu Pahat town. In the Mukim of Benut it was sold at $\$ 3.80$ to $\$ 6.5()$ and in Senggarang between $\$ 4.50$ to $\$ 7.40 .{ }^{100}$ The acreage of arecanuts declined over the years owing to poor prices. After each harvest the older trees were felled and sold at $\$ 20$ per hundred for the erection of fish traps.

The social order of Batu Pahat was historically huilt on its material bases. The expansion and contraction of the market economy was experienced by peasant small-holders, tenant farmers and coolies who worked the fields. They were located at the production level of the agricultural industry. Each fraction of the working class produced for exchange value. Their social product were appropriated by officials who were paid from taxes; landlords who lived on rent; merchants who bought cheap and sold dear and money-lenders who squeezed interests. In addition, the fortunes of the peasants fluctuated with the rise and fall of commodity prices. The state furthermore fattened the producing classes further through its revenue demands at production and exhange levels. The fillers of the sell were left eventually to extract their wages for daily survival.

The Malay producing classes reproduced the conditions of their subservience. An elderly Malay gentleman captured the historical experience with the statement "This is, and was, the land of the Malays. They lived here and were happy. They opened up the country - and wherever they went the Chinese followed with their money and trade stores... Gradually, heciuse of money [cash ecconomy?] most of the property fell into the hands of the Chinese...." The language of real life is interwoven with the material activity and material intercourse of classes entrenched in the global economy. 
66 Jurnal Sejarah

\section{Abbreviation}

$\begin{array}{lll}\text { GAJ } & - \text { General Adviser Johore } \\ \text { LOBP } & - \text { Land Office Batu Pahat } \\ \text { CLM } & - & \text { Commissioner of Iands and Mines } \\ \text { CLRBP } & - \text { Commissioner of Land Revenue Batu P'allat } \\ \text { ARJ } & - & \text { Annual Report Johore } \\ \text { AABP } & - \text { Assistant Adviser Batu Pahat }\end{array}$

